\title{
Managing Environmental Policies: Lessons From Traditional Communities
}

\author{
Roberta Freitas Lemos ${ }^{1}$ (D) C Célia Regina Neves Favacho ${ }^{2,3}$. \\ Kátia Cristina Favilla ${ }^{4}$ Fábio Henrique Baia ${ }^{5}$
}

Published online: 31 October 2019

C) Association for Behavior Analysis International 2019

\begin{abstract}
Natural resource conservation concerns have been prevalent around the world, and a range of solutions has been implemented to prevent their depletion. This paper brings together the literature on the commons and on behavioral principles to understand how traditional communities' management of common pool resources can contribute to this discussion. More specifically, it highlights how these communities can offer lessons to governments on how to develop and manage environmental policies to ensure sustainable development. Whereas Ostrom's work focuses on investigating how local communities succeed at managing common pool resources without external interference, behavior analysis can explain how cultural practices are selected. Through this combined framework, we investigate the practices of an extractive reserve (RESEX) in Brazil. A RESEX is an area of land, generally state owned, where access and use rights, including natural resource extraction, are allocated to local groups. The RESEX Mãe Grande de Curuçá is an example of common pool resource management that uses governmental tools to benefit the community. Fisherfolks are able to successfully conserve one of their main sources of livelihood: the fiddler crab. Finally, this paper describes and behavioral interactions regarding the conservation of resources that governments may want to consider.
\end{abstract}

Keywords Common pool resources · Traditional communities · Extractive reserve · Cultural selection · Public policy

People are continually using the planet's resources. Water, soil, minerals, plants, and animals are overconsumed daily with few controls regarding the long-term impact. However, natural resources are finite, and their conservation is crucial for the survival of humans. All living organisms benefit from the availability of natural resources

Roberta Freitas Lemos

robertafreitaslemos1@gmail.com

Extended author information available on the last page of the article 
now - and in the future. To conserve natural resources means not to consume them faster than they can be replaced.

Different approaches have been used to protect and restore natural resources. In 1990, Ostrom observed that control by the state or by the private market was a solution commonly suggested to prevent the destruction of natural resources. However, Ostrom (1990) noted that natural resources do not necessarily need to become public goods (controlled by the government) or private goods (controlled by the market) in order to be conserved. After carrying out field studies, she observed that communities of individuals may be able to self-organize a productive use of a natural resource system that succeeds in maintaining people's behavior over long periods of time - an alternative solution to those that had been previously suggested.

Although Ostrom's (1990) studies were focused on the practices of these communities, she did not eliminate the possibility of government and private market participation in the conservation of natural resources. Opportunely, she suggested that central authorities could learn from local communities. Bringing together the literature on the commons and behavioral principles can be useful to understand how local communities' management of common pool resources (CPRs) can contribute to providing real cases that support Ostrom's model and the associated behavioral interpretation of it.

As a controlling agency that is able to control the behavior of a large number of people (Skinner, 1953), the government should formulate and implement policies to ensure the sustainable development of the planet. Through the study of cultural practices maintained by local communities that have demonstrated how not to overharvest resources, we are especially interested in highlighting the lessons that can be learned by the government in their management of environmental policies. The correct diagnosis of variables that affect the behavior of people is useful to better inform policy makers who design interventions to alleviate natural resource depletion.

The aim of this paper is to demonstrate how behavioral science and institutional analysis can inform the design of environmental policies and help promote large-scale social change. This analysis will address the following questions:

1. What are the behavioral processes and procedures involved in the selection of cultural practices that can be observed in self-organized, self-governed, and longendurance CPR regimes, according to Ostrom's (1990) core design principles?

2. How can the government help promote cooperative behavior and avoid economic self-interested behavior by supporting the management of the resources by local communities?

The paper is divided into five sections. The first section calls attention to the background of Ostrom's (1990) guidelines for managing CPRs. The second section indicates extractive reserves (RESEXs) in Brazil as a possible pool of case studies and briefly presents some cultural practices of the inhabitants of the RESEX Mãe Grande de Curuçá. The third section explores Ostrom's principles to extract the possible behavioral processes and procedures implied, describes some examples from the RESEX Mãe Grande de Curuçá, and makes some policy recommendations. The fourth section gives an overview of the behavioral principles and the cultural practices selected at the RESEX Mãe Grande de Curuçá. The last section presents final considerations. 


\section{The Role of the Government in Enhancing Self-Governance in CPRs}

Garret Hardin's seminal paper titled "The Tragedy of the Commons" (Hardin, 1968) described the dilemma of a common resource system where self-interested behavior, or behavior directed toward obtaining the most personal benefit, leads to the depletion of resources, jeopardizing the maintenance of the common good for all users. The classic example describes a pasture open to all herders to keep their cattle. To maximize their individual gain, each herder keeps adding animals without limits, contributing to what results in overgrazing. The tragedy of the pasture depletion takes place, and the resource is not useful to anyone else any longer.

This situation resembles ethical self-control, as proposed by Borba, Tourinho, and Glenn (2017). According to Borba et al. (2017), when members of a group face a choice in a situation that offers either immediate gain for oneself or delayed gain for the group, self-control would be characterized as choosing the delayed gain for the group. In this sense, conditional relations must be created to ensure that the consequences for the group are more effective than the consequences for the individual; otherwise, the members of the group will choose the smaller and immediate individual gain, which will culminate in the tragedy of the commons.

Based on this scenario in which people do not cooperate to produce a shared outcome (the maintenance of the resource for future use), but rather pursue their own short-term interest leading to a suboptimal outcome (i.e., the immediate individual gain, but the delayed loss associated with the overuse of the resource for the entire community gravitating around the commons), Hardin (1968) questioned the capacity of the collective management of common resources. He believed that members of a group could not find successful solutions to collective problems (i.e., problems affecting an entire community when the individuals emit specific behaviors) without relying on external rules. Moreover, Hardin defended coercion as the only mechanism capable of inhibiting the depletion of common resources. His statements had an essential role in influencing scholars to believe that only external agents, such as the state or private markets, could regulate the use of natural resources (Ostrom, Walker, \& Gardner, 1992).

In a different direction, Ostrom (1990, 2000, 2002, 2005; Ostrom \& Ostrom, 1971; Ostrom et al., 1992) dedicated her studies to researching local communities' governance of common resources. Ostrom's general findings, both from laboratory research and from natural experiments, suggested that members of a group are capable of successfully cooperating and managing shared resources without relying on external regulations. Furthermore, she argued that imposed external rules could even crowd out cooperative behavior.

In laboratory settings, Ostrom et al. (1992) and Ostrom (2000) observed that cooperative behavior controlled by external rules tended to disappear very quickly. Despite this, Ostrom (2000) also observed that cooperative behavior controlled by a collective agreement tended to be maintained over extended periods of time. Along the same line, field observations suggested that community members were able to develop joint strategies and basic rules to manage resources more efficiently than when rules were enforced by an external agent (Ostrom, 1990, 2000, 2002). Hence, these studies opened up a new debate toward the review of the traditional thesis that stated that the market and the government were the only two ways to manage the overuse of CPRs: "Our findings challenge the Hobbesian conclusion that the constitution of order is only 
possible by creating sovereigns who then must govern by being above subjects, by monitoring them, and by imposing, sanctions on all who would otherwise not comply" (Ostrom et al., 1992, p. 414).

After researching several self-organized, self-governed, and long-surviving resource regimes, Ostrom $(1990,2005)$ formulated a set of eight principles characterized in CPR systems. ${ }^{1}$ These principles referred to specific elements that accounted for the success in promoting sustainability that were passed down through generations. Cox, Arnold, and Tomás (2010) reviewed the design principles after analyzing 91 studies. Cox et al. verified that the principles are well supported empirically and suggested some subdivisions that will be further detailed in later sections.

Nonetheless, Ostrom's (2000, 2002, 2005; Ostrom \& Ostrom, 1971; Ostrom et al., 1992) work did not suggest a complete substitution of the government by community self-governance. Instead, she pointed to the need to develop an alternative theory of public administration that considers a variety of multiorganizational arrangements supported by a diversity of communities of interest, as opposed to a more traditional theory that suggests a unique top-down direction from a single bureaucratic structure. In addition, Ostrom supported new arrangements that would provide adequate public services to a number of different collectivities, rather than those provided by a hierarchical authority that coordinates public services. Moreover, she advocated for a complementary role between government and civil society in order to achieve a high level of performance in addressing CPR management and advancing social welfare (Ostrom, 2000, 2002, 2005; Ostrom \& Ostrom, 1971; Ostrom et al., 1992). When describing how to broaden the concept of policy analysis, Ostrom (2002) wrote,

National governments will remain among the targets of advice, but greater attention should be devoted to regional and local governments. More importantly, one of the important targets for all policy analysis in the future should be citizens organized in diverse ways related to a multiplicity of issues. (p. 42)

Ostrom (2002) justified her appeal; public policy shall not be an exclusive domain of any scientific discipline or area of knowledge. An optimal solution to a complex issue needs to take its multiple facets and diversity into account. A conjoined effort creates an arena for experimentation and provides a better means of evaluation (Ostrom, 2002). In the next section, we describe how RESEXs in Brazil can provide elements for the study of CPRs, both those managed by local users and those supported by the government.

\section{The RESEXs in Brazil}

In the early 1980s, the rubber tappers who inhabited the Amazon rain forest were suffering from traders' violence and exploitation in addition to forest felling by farmers,

\footnotetext{
${ }^{1}$ Ostrom (1990) refers to the terms robust, fragile, or failure to characterize a CPR's institutional performance regarding every principle. When referring to the CPR settings described in her book Governing the Commons, Ostrom (1990) states that "the most notable similarity of all, of course, is the sheer perseverance manifested in these resource systems and institutions. The resource systems clearly meet the criterion of sustainability. The institutions meet Shepsle's (1989b) criterion of institutional robustness, in that the rules have been devised and modified over time according to a set of collective-choice and constitutional-choice rules" (p. 89).
} 
which was preceded by the expulsion of the families and the appropriation of the land. At that time, a movement began to seek the visibility of the struggles faced by the local communities and their recognition as "the people of the forest," with legitimate social and agrarian rights (Almeida, 2004).

In 1985, an event was held in Brasília (the federal capital), in which different leaders from remote Amazonian sites, including politicians, bureaucrats, technicians, professors, and students, participated. On this occasion, leaders exposed their local problems. They were surprised at the authorities' complete lack of planning and knowledge of the reality of the rubber plantations. Thereafter, the leaders created the National Council of Rubber Tappers (CNS) in an effort to organize themselves at the national level (Almeida, 2004).

The CNS started discussing their collective claims and came up with a definition of the RESEXs. After analyzing alternatives such as individual ownership and common property, they understood that none of these would eliminate the risk that the land would be sold to farmers. Only collective occupation, without the possibility of commercialization, would aid in the avoidance of the threats of privatization of resources. Thus, the CNS definition of RESEXs included those lands in the union that the families would hold the perpetual right of usufruct (the right to use and take advantage of a property short of the destruction or waste of its resources; Almeida, 2004).

Subsequently, the CNS started holding meetings with extractivists in various Amazonian states with the aim of strengthening the different forms of collective organization and discussing the local problems and the proposal to transform large areas of the forest into public areas for use according to traditional practices. Meanwhile, there was constant back-and-forth communication with the government to achieve the goal of creating RESEXs (Almeida, 2004). The first RESEXs in Brazil were created by presidential decree in the 1990s, presenting a new paradigm of sustainable development with popular participation.

A few years later, the government also recognized that marine and coastal areas should be protected as an essential strategy for the conservation and sustainable use of marine and coastal biodiversity. In 1992, after an effort to extend the concept of RESEXs to these areas, the first marine RESEX was created in Brazil. The new areas delimited territories for exclusive use by artisanal fisherfolks.

The discussion of the regulation of protected areas in Brazil lasted more than 10 years. Legal security for the new model as a state policy arose with the publication of the National System of Conservation Units (NSCU), ${ }^{2}$ established by federal law and regulated by decree. ${ }^{3}$ The NSCU divided protected areas into two groups: full protection and sustainable use. The aim of full protection units is to preserve natural resources, allowing only their indirect use (i.e., scientific research, visitation for educational purposes, and ecotourism), and saves them for special cases. The goal of the sustainable use units is to harmonize the conservation of natural resources and their sustainable use.

Each group includes different types of areas. A RESEX is a type of sustainable use protected area. The law foresees that the use rights of this state-owned land are

\footnotetext{
2 The existence of a stable and legal framework to protect the initiative.

${ }^{3}$ Federal Law No. 9985/2000 and Decree No. 4340/2002.
} 
allocated to a local, traditional community whose subsistence is based on extractivism, agriculture, and raising small animals. The main objective is to protect the way of life and the culture of the locals and to promote the sustainable use of natural resources within that unit's area.

The law also states that a deliberative council, composed of public bodies and representatives from the traditional communities, will manage a RESEX. Representatives from the traditional communities also compose the majority. A local management plan, approved by the council, would describe the rules, the restrictions on use, the actions to be developed, and the guidelines for managing resources.

The design of RESEXs presents the idea that, for purposes of environmental conservation, the right to use land in the public domain is granted to the local community. The government plays an active role in ensuring interactive governance in the area, which means that they "recognize traditional uses, practices and knowledge as instruments to ensure the present and future generations a healthy and balanced environment" (Pinheiro, Thomas, Almeida, \& Vergara, 2018, p. 4). Therefore, the local community is directly responsible for the management of natural resources with the support of the government.

For this reason, we believe that RESEXs in Brazil represent a pool of case studies that can be considered in order to understand the potential role of the government in supporting local management of natural resources. In the next subsection, we give an overview of a marine RESEX we chose to illustrate the analysis that follows. The information was collected through official documents, academic studies, and interviews with locals.

\section{RESEX Mãe Grande de Curuçá}

To illustrate how traditional communities can inform public policy, we chose a marine RESEX, located in the city of Curuçá in the northeast of the state of Pará in Brazil. Curuçá is known for its diversity of species of fish and shellfish, such as shrimp and crab. It is also widely recognized as a traditional and important fishing site in the Amazon. Since 1997, different actors have been engaged in community mobilization to identify and address solutions to local problems related to the overuse of their natural resources by external agents (Souza, 2010).

In 2002, the government created the RESEX Mãe Grande de Curuçá (Decree w/n from 12/13/2002) and defined its borders. The name, which was chosen by the community itself, refers to the idea of a common origin (translated as "great mother"). The area contains 37,062 hectares of estuary, a region where river waters interact with the ocean. ${ }^{4}$

In 2006, the government created a deliberative council with the aim of contributing to the implementation of the RESEX's objectives and its management plan (Federal Ordinance No. 24/2006). The deliberative council is composed of 5 members from the government, 2 from universities, and 20 members from civil society. The Chico Mendes Institute for Biodiversity Conservation (ICMBio) ${ }^{5}$ is the official management

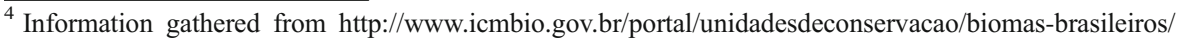
marinho/unidades-de-conservacao-marinho/2279-resex-mae-grande-de-curuca

${ }^{5}$ ICMBio is a federal agency linked to the Ministry of Environment that has administrative and financial autonomy. Its agents also exercise environmental police power over the conservation units.
} 
agency and the president of the council. In 2010, the government agency assigned the right of use of the reserve to the users of the association (Associação dos Usuários da Reserva Extrativista Mãe Grande de Curuçá) for a period of 20 years (extendable for successive periods of 20 years). The fishing community is presided over and supported by the deliberative council. The management plan is still being drafted; however, a utilization plan regulates the exploitation of natural resources.

The RESEX is populated by 52 small communities located on islands, rivers, and beaches (Souza, 2010). The traditional communities that live in the RESEX possess an empirical knowledge about that environment, built through the historical relation of its members with that territory. The main socioeconomic activities relate to marine extractivism (artisanal fishing and shellfish), vegetal extraction (harvesting of forest products), and subsistence agriculture (growing enough food crops to feed a family; Batista \& Simonian, 2013; Souza, 2010). Batista and Simonian (2013) claimed that the traditional practices that combine these three activities, having been transmitted from generation to generation, have historically ensured the survival of the local community. They noted that these activities have had few significant impacts on natural resources and that possible changes to this scenario are caused by external factors. One factor, for example, is the presence of large enterprises related to industrial fishing that impose predatory exploitation of natural resources around the area.

One of the most explored natural resources of the RESEX Mãe Grande de Curuçá is the fiddler crab. Two thousand families are completely dependent on crab fishing. Another 3,000 families are partially dependent on crab fishing, with some reliance on alternative sources of income. ${ }^{6}$ Aside from being one of the main sources of income for local families, the crab has multiple uses and meanings for the local community. It provides food security; it is the main ingredient for a variety of dishes, such as salads, crumbs, soups, pies, risotto, pasta, snacks, and other typical specialties. The crab also plays different roles in the local cultural traditions and is part of prayers, stories, and dances.

The families that live on the reserve are allowed to fish. There is no schedule the families must follow as to when they are allowed to catch crabs. Each family is responsible for their own catch, and they are not obliged to share it with the community. Although there is not an existing custom about sharing resources, there is a communal agreement (a fishing partnership) between the members of the community who partner with one another to go deep-sea fishing. The production is divided into 4.5 parts: 2 parts go to the owner of the tools, 1 part goes to each one of the two fisherfolks, and 0.5 goes to the owner of the canoe.

In addition, there is not a formal division of labor between men and women. Nevertheless, the men are usually more involved in deep-sea fishing, and the women prefer to catch crabs on the igarapés (small bodies of water, generally a tributary river or a canal) when the tide is low. Most women are also involved in other activities such as tool construction and repair, product trade, interactions between and among families, and family care. The children in the community are taught to collect crabs by observing and joining the adults.

There are two main threats to the conservation of fiddler crabs. The first is predatory fishing with the widespread use of illegal fishing gear and methods. The second is the

\footnotetext{
${ }^{6}$ Information gathered from a deliberative council representative.
} 
installation of shrimp farms. The shrimp farms are built on the area in the estuary where the female crabs lay their eggs. The shrimp farms then compete with the female crabs for space in the estuary, restricting or even resulting in the loss of the crabs' habitat for laying eggs.

Crab fishing is closely regulated; a ministerial order was published that prohibits people from harvesting the crabs during specific periods of time. Other restrictions that must be followed can be found in the utilization plan, the fishing deal between the community and the government, and in environmental legislation (NSCU, Federal Law No. 9.605/1998, and others).

In the next section, we use Ostrom's (1990) work to further consider some of the cultural practices maintained by the RESEX's inhabitants and to identify the behavioral processes responsible for their selection.

\section{A Behavior-Analytic Interpretation of Ostrom's Eight Core Design Principles}

As previously noted, Ostrom $(1990,2005)$ formulated eight principles based on the observation of similar practices implemented in several self-organized, self-governed, and, above all, long-enduring CPR regimes. For each principle, she described essential elements or conditions that might be found in successful CPR systems. Further, Ostrom (2000, 2005) asked for help in comprehending how some contextual variables would enhance cooperation, whereas others would discourage it. Ostrom (2000) continued,

We need to understand how institutional, cultural, and biophysical contexts affect the types of individuals who are recruited into and leave particular types of collective action situations, the kind of information that is made available about past actions, and how individuals can themselves change structural variables so as to enhance the probabilities of norm-using types being involved and growing in strength over time. Further developments along these lines are essential for the development of public policies that enhance socially beneficial, cooperative behavior based in part on social norms. (p.154)

In this regard, behavior analysis might be able to help. The focus area within behavior analysis, cultural analysis, has led to advancements in our understanding of the variables that promote and discourage cooperation (see Glenn et al., 2016, and Houmanfar, Rodrigues, \& Ward, 2010, for key concepts related to this analysis). In analyzing cultural phenomena, there is a shift in the focus of attention from how a contingency arrangement may affect the behavior of one person to how it can affect the behavior of more than one individual that may or may not be interlocked (cf. Glenn, 2004).

Skinner's (1953) discussion of controlling agencies, or those who have the ability to manipulate a particular set of variables consistently and accurately to affect the behavior of many individuals, may also be particularly useful. A controlling agency is the part of a group that exerts ethical control over the behavior of its members. Governments, for example, are controlling agencies that classify behaviors as acceptable/legal or unacceptable/illegal. Governments frequently apply behavioral 
procedures such as reinforcement and punishment to control behavior. The procedures (or controlling practices) are usually codified by issuing rules and regulations. Sometimes these rules or regulations take the form of statements that are intended to strengthen controlling practices already operating in the group. At other times, the goal is to promote new practices or to eliminate existing practices.

What follows is an exploratory analysis in which we propose a behavioral approach to the study of the set of principles designed by Ostrom (1990). In this approach, attention is shifted to the identification of possible behavioral processes and procedures that can be extracted from each principle, interpreted from a behavior-analytic lens. The reconstitution of the behavioral processes and procedures of the RESEX Mãe Grande de Curuçá is used to illustrate this attempt. Following the behavioral analysis of each of Ostrom's principles are policy recommendations that are based on the analysis. Importantly, what we propose is not intended to reduce the potential contributions of behavior analysis to Ostrom's work. Rather, the analysis is meant to suggest some guidelinesinspired by Ostrom's core design principles and reinterpreted in behavior-analytical terms - that may be useful for governments in order to promote the conservation of natural resources by supporting the traditional communities that have historically protected CPRs (i.e., did not overuse CPRs). In it, we consider how minimal intervention from the government can assist traditional communities in their management of CPRs without threats imposed by internal and external agents.

\section{Core Design Principle 1: Clearly Defined Boundaries}

Ostrom (1990) first described this principle as follows: "Individuals or households who have rights to withdraw resource units from the common-pool resource (CPR) must be clearly defined, as must the boundaries of the CPR itself' (p. 91). Ostrom (2005) referred to this first principle as the first step to prevent free riders (in this case, people who benefit from the CPR without expending any effort for its protection or conservation) and to organize collective action. Cox et al. (2010) proposed the following subdivisions:

1. "Individuals or households who have rights to withdraw resource units from the common-pool resource (CPR) must be clearly defined" (Cox et al., 2010, Table 3). This statement clarifies the necessity of defining who can harvest the resources. It draws the boundaries of who is entitled to use the natural resource and who is not entitled to its use. Subsequently, someone will need to exclude the outsiders.

2. "The boundaries of the CPR must be well defined" (Cox et al., 2010, Table 3). This statement calls for the need to define the environment in which the rules regarding the use of the CPR are valid. Setting geographic limits clarifies what is being managed and highlights the need for everyone to understand the geographic boundaries of the CPR.

From a behavioral point of view, this principle and its subdivisions seem to point out how contingency arrangements could prevent outsiders' access to the CPR. Social and geographic boundaries define antecedent conditions, which signal diverse consequences for different situations. For example, in a limited area, if a community member accesses the CPR, he or she might receive approval from other community users and 
money from its sale. On the contrary, in the same area, if an outsider accesses the CPR, he or she might receive disapproval from community users and a fine from the authorities.

Considering that the CPR is finite, its exploitation by outsiders decreases the number of available reinforcers for the community members. This means that the exploitation of a CPR by outsiders can alter the cost-benefit ratio of cooperative behavior for the community members. If there are not enough reinforcers available for everyone, it is possible that the community members will engage in different behaviors that might be incompatible with CPR conservation.

In this scenario, it seems that it is essential to find powerful consequences that can control the behavior of outsiders. The outsider's behavior of withdrawing the resources might produce two different consequences: (a) the natural resource that could be exchanged for money, increasing access to other reinforcers, and b) the community's disapproval that might involve complaints and the enforcement of formal sanctions by the authorities. The first consequence would be expected to increase the likelihood of the outsider's behavior through positive reinforcement. The latter would be expected to decrease the likelihood of the outsider's behavior through positive punishment. In order to suppress the behavior of the outsider, the latter consequence (b) needs to overcome the effects of the former (a). One possible contingency arrangement might ensure that the monetary value of the fine imposed for outsider's use of the CPR is greater than the monetary value of the sale of the resource withdrawn. This arrangement might prevent the withdrawal of the resources by outsiders.

In the case of the RESEXs in Brazil, following several rounds of discussion between government officials and the users associations' representatives, a presidential decree defined the exact limits of the protected area through geographical coordinates, a distinction that might favor the development of stimulus control for outsiders' behavior regarding the areas in which special rules for withdrawing resources are in place. In addition, the right of use was assigned to the users of the association for a specific period of time. The association representatives are then able to define who can withdraw the natural resources in the RESEX (i.e., who is considered a community member). If a nonauthorized person (i.e., an outsider) withdraws the resources, the competent agency that has environmental police power can apply sanctions, such as fines, as defined in the law. ${ }^{7}$ Well-defined sanctions and procedures to punish illegal behavior by outsiders might assist in decreasing free riding.

The RESEX Mãe Grande de Curuçá had its geographic boundaries set by decree in 2002, and in 2010, the government assigned the control to define the social boundaries to the association. The association has not yet defined who is entitled to harvest the resources, which makes it difficult to effectively inhibit outsiders from withdrawing CPRs and to punish their behavior. On two occasions, population censuses were carried out to identify potential appropriators. The first set of census data was lost during a governmental transition, and the deliberative council did not approve the method and results of the second census. A new census has been approved for 2019 .

Considering the lack of rigid control of the social boundaries, a member of the deliberative council explained,

\footnotetext{
${ }^{7}$ Federal Law No. $9605 / 98$
} 
Let's say that $90 \%$ of the inhabitants of the municipality of Curuçá usually go fishing. For some of them, it is the main source of occupation. For others, such as public servants, police officers, and doctors, it is a source of entertainment, a sport, or a family tradition. None of them cause damage to the environment. The problem is the external invasion for predatory extraction. For example, the SEBRAE [the Brazilian Micro and Small Business Support Service] disclosed the potential of the oysters in the area and ended up attracting entrepreneurs who looted the natural resources, threatening the species. (member of the deliberative council, interviewed on February 23, 2019)

Apparently, the definition of boundaries in RESEXs involves at least two culturants (cf. Glenn et al., 2016):

1. To define geographic boundaries (an aggregate product), government officials and community members have to discuss and agree on the limits of the protected area (interlocking behavioral contingencies).

2. To define social boundaries (an aggregate product), government officials need to assign the right of selecting the potential users to the association representatives who make a list, which may be approved by the government (interlocking behavioral contingencies).

Some potential actions that policy makers could engage in to favor the successful implementation of Core Design Principle (CDP) 1 might include (a) shortening the time gap between defining the geographic and social boundaries; (b) ensuring community members' participation in the roundtable discussions to define geographic boundaries, as both parties need to agree on the limits of the protected area; (c) offering support for and following up on the work of association representatives in defining the potential appropriators; and (d) ensuring that the established boundaries, especially the consequences for breaking the rules, are broadly disseminated.

We suggest these actions in an attempt to help promote interlocking behavioral contingencies to produce the aggregate products of the agreements between community members and government officials regarding the boundaries of the protected area, the community members, and the outsiders. Namely, these recommendations could help to ensure the strict application of the consequences for outsiders and to promote continual evaluation as to whether the defined consequences have successfully prevented external threats. Once the aggregate product has been produced, it would also be important to demonstrate how it would allow one to differentiate who is a community member from who is an outsider and which area belongs to the RESEX and which area does not. These aggregate products would then be antecedent conditions for reporting illegal behaviors that should be adequately punished. The aim is to suppress inappropriate behaviors in an effort to increase the chance of conservation of the CPR.

\section{Core Design Principle 2: Congruence Between Appropriation and Provision Rules}

Ostrom (1990) explained this principle as follows: "Appropriation rules restricting time, place, technology, and/or quantity of resource units are related to local conditions and to provision rules requiring labor, material, and/or money" (p. 92). After defining 
who is in and who is out in a set of relationships, rules would regulate the behavior of those who can withdraw the natural resources (Ostrom, 1990, 2005). The objective is to ensure that appropriators who invest in the conservation of the natural resources receive a proportional return. Cox et al. (2010) separated this principle according to two different conditions. The first was the conformity between appropriation rules and local conditions. The second was the congruence between appropriation and provision rules. Both are detailed as follows:

1. "Appropriation rules restricting time, place, technology, and/or quantity of resource units are related to local conditions" (Cox et al., 2010, Table 3). The rules have to specify the time, the place, the amount, and the technology used to harvest the resources. Rules need to match local customs, livelihood strategies, and the conditions of the CPR. This condition makes evident the importance of consulting the local communities that have traditionally harvested the resources.

2. "The benefits obtained by users from a CPR, as determined by appropriation rules, are proportional to the amount of inputs required in the form of labor, material, or money, as determined by provision rules" (Cox et al., 2010, Table 3). This condition seems essential to maintain the cooperative behavior of the appropriators. Users will only comply with the appropriation rules if the benefits from withdrawing resources are proportional to the efforts required to conserve the CPR. The users' evaluation of the cost-benefit ratio in terms of their cooperative behavior helps with the establishment of a fair system.

From a behavioral perspective, rules are verbal stimuli that describe contingencies of reinforcement (Skinner, 1969). Matos (2001) noted that rules are a special type of discriminative stimulus because they involve the behavior of the person who issues the rule, which requires an understanding of the context in which the verbalization was issued. CDP 2 highlights how contingency arrangements (a) install and maintain the behavior of harvesting the CPR that produces CPR conservation and (b) ensure that users will provide what is necessary to produce CPR conservation. CPR conservation is a cumulative effect of repeated patterns of behavior in a macrocontingency. The first subdivision specifies that the behavior of describing the requirements regarding the approval or disapproval of harvesting the resources needs to be under the control of the local conditions and the conditions of the CPR itself. From this point of view, it seems advantageous if those who know the environment and depend on it to survive are the ones who emit the behavior of describing the requirements in correspondence to the analysis suggested by Matos (2001). Nevertheless, this does not mean that the government or universities cannot support the decision-making process. These rules serve as antecedent conditions for the behavior of harvesting the resources.

However, as demonstrated by Galizio (1979), the behavior of rule following is also reinforced by its respective consequences. Thus, as important as it is to describe the conditional relation involving antecedent events, behavior, and consequences pertaining to the allowable or disallowable use of the CRP, it is also important to ensure that the consequences that maintain rule following are also delivered. This emphasizes the importance of the second subdivision Cox et al. (2010) offered.

The second subdivision points out the importance of verifying whether the consequences (e.g., the income obtained from the CPR) effectively control the behavior of 
harvesting the resources in accordance with the predetermined conditions (appropriation rules and provision rules). An evaluation of the cost-benefit ratio of following the rules and not following the rules may be helpful. In one situation, if some requirements are met, harvesting the resources will be reinforced. In another situation, and if the requirements are not met, harvesting the resources might be punished (if it is not, it might be reinforced). The more conditions there are that need to be met regarding appropriate or inappropriate harvesting, the more conditions there are that require the arrangement of punishment contingencies. The situation can be further restricted by adding antecedent conditions, such as a short duration for allowable extractions, a limited area in which harvesting can occur, or the requirement of specific topographies of harvesting behavior such as the obligation to use a special technology or method, or altering the parameters of the contingency by strictly specifying the amount of the CPR allowed per person. Each additional requirement will further constrain the conditions under which harvesting the resources is reinforced, simultaneously expanding the conditions under which harvesting the resources can be punished.

Paralleling the consideration of rules and consequences for allowable and disallowable extraction, it is also necessary to consider alternative behaviors that can be emitted to obtain similar reinforcers (i.e., income). For example, in the same situation in which harvesting the target resources can be punished, is it possible to harvest other types of resources? The availability of alternative responses, for which engaging in different behaviors can produce similar consequences (i.e., income), might change the probability of harvesting the target resources when restrictions are in effect.

It is important to highlight that for both appropriation and provision rules, the behaviors of the people who are making the rules are also under the control of environmental events. This likely prevents insensitivity to changes - an effect that is well documented in the instructional control literature (e.g., Galizio, 1979). Because rules are issued in the natural context, changes in this environment result in changes to the issued rules.

In the case of the RESEX Mãe Grande de Curuçá, the appropriation rules are formulated and constantly reviewed, taking into consideration the conditions of the CPRs in a conjoined evaluation effort between the communities, the universities, and the government. A member of the deliberative council reported,

The rules are always changing. Everything depends on the development of the community, on nature itself, on the climate changes and other aspects. Many studies are carried on at the RESEX by community members and members of the universities to evaluate the conditions of the natural resources and crab fishing. (member of the deliberative council, interviewed on February 6, 2018)

In 2018, a poster released in the community illustrated some of the appropriation rules for that year. ${ }^{8}$ The poster explains that andada or Suatá is a specific period of the year (from January until March) during the full moon and the new moon, during which the male and female crabs leave their burrows and walk through the mangrove for mating and releasing eggs. At this moment, when they are out of the burrows, they become

\footnotetext{
${ }_{8}$ There are other appropriation rules that regulate the capture of crabs, such as the techniques that are allowed. We decided to use these to illustrate our point regarding this principle.
} 
vulnerable to capture. The measure has two related objectives: to preserve the reproduction of the species and to ensure that the number of crabs is sufficient for the collectors who depend on the crabs' sale for livelihood. The majority of the production is sold to an intermediary, who is responsible for selling it to customers, such as restaurants and others. In addition, the government supported the construction of a municipal market to facilitate the commercialization of fish and shellfish (Souza, 2010).

In Figure 1, two opposing situations can be identified. The first situation shows when crab fishing is allowable. The second situation points out the condition under which crab fishing is not allowed. Crab fishing can be an individual activity or a collective activity (e.g., when community members go deep-sea fishing). The two situations are described in Figure 2.

Community members can engage in several other activities as alternative sources of income, especially when they are not allowed to catch crabs. Alternative behaviors might include the collection of native fruits or nuts and fishing for other varieties of sea creatures. This third situation is described in Figure 3.

Another example regarding the transportation of crabs illustrates the provision rules. Historically, community members have transported the collected crabs in two different ways: pencas (the crabs are tied up together with a string) or the crabs are placed in bags. A third method, called basquetas (the crabs are transported in plastic boxes protected by sponges), however, has recently been created in a partnership between fisherfolks from a close RESEX and a government agency. When the first two methods are used, the mortality rate of crabs ranges from $35 \%$ to $45 \%$. When the last method is used, the mortality rate decreases to $4.6 \%$ and the crabs survive up to 6 days. ${ }^{9}$ The local community has incorporated the new method in their provision rules, which suggests effective practices both in issuing rules and in following the instructions due to their accuracy. The government supported this decision by publishing a normative instruction that regulates the transportation of crabs. Graduated sanctions can also be applied if basquetas are not used.

The use of basquetas can make the activity more profitable for both appropriators (they need to collect fewer crabs to get the same amount of money) and for company owners (they can store the crabs for a longer period). However, aside from being a cheap technology, the materials are still more expensive than the ones used in the other transportation methods. In order to decrease the costs of using basquetas, the government donated the first sets of plastic boxes and sponges for the deliberative council to distribute among the fisherfolks.

Ostrom's (1990) CDP 2 encourages the specification of the behavioral processes and procedures involved in the maintenance of cooperative behavior if the rules are followed. Regarding the RESEX Mãe Grande de Curuçá experience, an analysis of the appropriation and provision rules allows for the description of the reinforcement and punishment procedures that are applied to harvesting the target resources in different contexts. It also calls attention to the importance of identifying and describing

\footnotetext{
${ }^{9}$ Information given by a governmental agent from the State Secretary of Fishing and Aquaculture to a state news website:

http://agenciapara.com.br/Noticia/66884/caixas-de-plastico-para-transporte-vao-reduzir-mortalidade-docaranguejo
} 


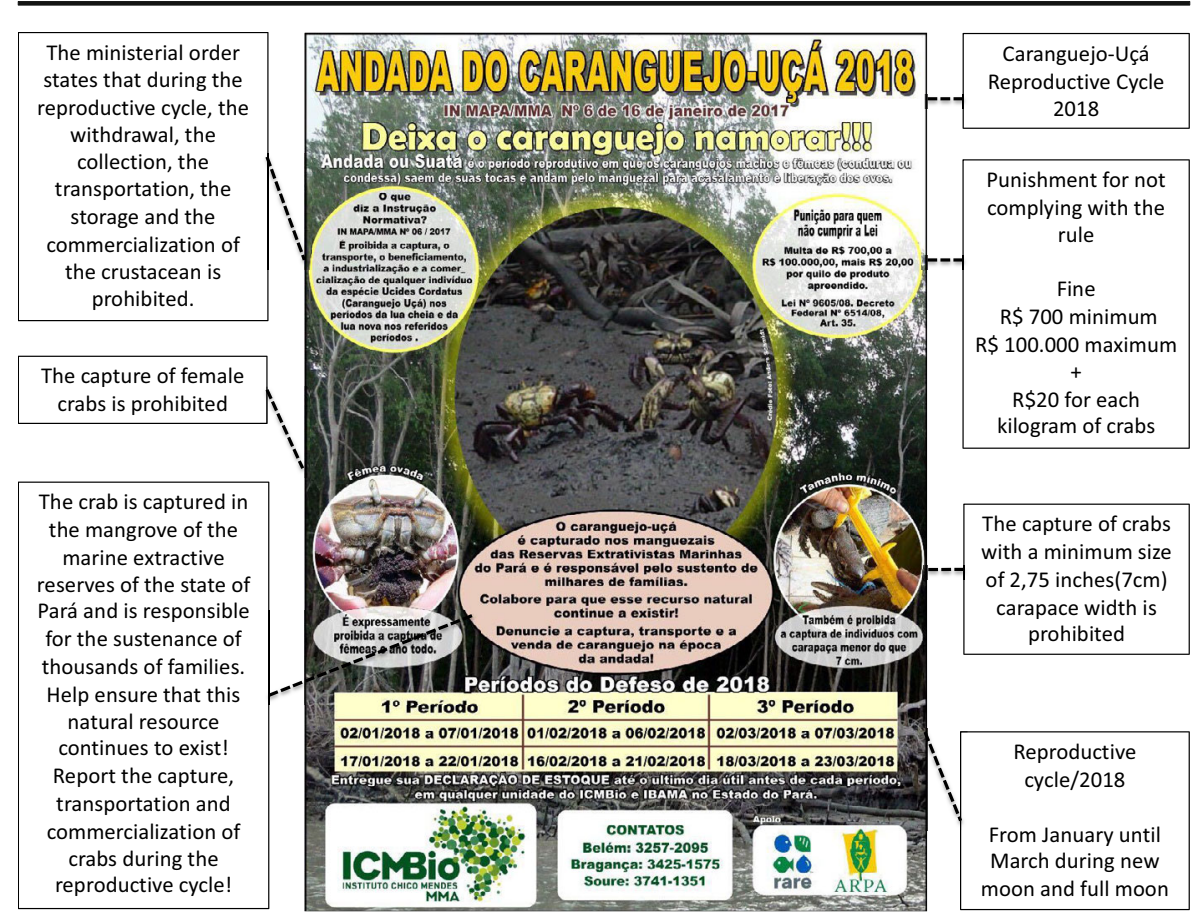

Fig. 1 Campaign-advertising poster for mangrove protection in 2018. Source: ICMBio

alternative behaviors that the appropriators can engage in to produce similar reinforcers when harvesting the resources is not allowed.

Policy makers could engage in one or more of the following actions that favor the successful implementation of CDP 2: (a) supporting roundtable discussions between the community and universities about the conditions of the CPR and (b) funding

\section{Situation A - Permission}

\begin{tabular}{|c|c|c|}
\hline $\begin{array}{c}\text { Antecedent condition } \\
\text { Male crabs } \\
+ \\
\text { Crabs with a minimum size of } 2.75 \\
\text { inches }(7 \mathrm{~cm}) \text { carapace width } \\
+ \\
\text { Any month of the year during waning } \\
\text { moon and waxing moon and from } \\
\text { April until December during new } \\
\text { moon and full moon }\end{array}$ & $\begin{array}{c}\text { Behavior + effect } \\
\text { or } \\
\text { Interlocked behaviors + aggregate } \\
\text { product }\end{array}$ & $\begin{array}{c}\text { Consequence } \\
\text { or } \\
\text { Cultural consequence } \\
\text { Community approval }\end{array}$ \\
\hline
\end{tabular}

\section{Situation B - Prohibition}

\begin{tabular}{|c|c|c|}
\hline $\begin{array}{c}\text { Antecedent condition } \\
\text { Female crabs } \\
+ \\
\text { Crabs with a maximum size of } 7 \mathrm{~cm} \\
\text { inches carapace width } \\
+ \\
\text { From January until March during new } \\
\text { moon and full moon }\end{array}$ & $\begin{array}{c}\text { Behavior }+ \text { effect } \\
\text { or } \\
\text { Interlocked behaviors + aggregate } \\
\text { product } \\
\text { Crab fishing/box of crabs }\end{array}$ & $\begin{array}{c}\text { Consequence } \\
\text { or } \\
\text { Cultural consequence } \\
\text { Community disapproval }\end{array}$ \\
\hline
\end{tabular}

Fig. 2 Appropriation rules: contingencies and metacontingencies for collecting crabs 


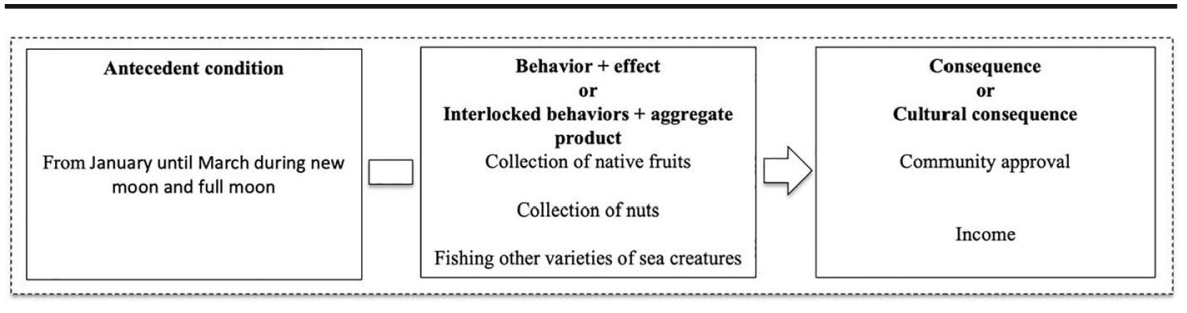

Fig. 3 Appropriation rules: contingencies and metacontingencies for harvesting alternative resources

scientific research that aims to answer questions raised by the community. Both actions are intended to establish systematic sources of information that could provide input into decision making. It is imperative to increase the opportunities in which rule-making behavior is influenced by changes in the environment in order to generate new and accurate rules. Following this process, policy makers could (a) support the decisionmaking process by codifying the rules created, (b) ensure that the appropriation and provision rules are widely communicated, (c) find strategies to improve the cost-benefit ratio of rule following, (d) offer subsidies for alternative behaviors (incompatible when possible) or other incentives such as tools for collecting other types of resources or seeds for plantations with the aim of increasing the probability of engaging in an alternative behavior and decreasing the costs of cooperating, and (e) ensure that similar consequences are available for alternative behaviors during the period(s) when the resources cannot be harvested. For example, in these said periods, the government could purchase agricultural products from CPR regimes and donate them to public institutions, such as schools or long-term care facilities. The third and fourth actions will increase the likelihood that rules will exert control over the behavior of community members, as they increase the probability that rule-following behavior will be reinforced. The next principle further explores how to ensure that the rules created are accurate and fit within the context of the natural environment.

\section{Core Design Principle 3: Collective Choice Arrangements}

Ostrom (1990) explained this principle, stating, "most individuals affected by the operational rules can participate in modifying the operational rules" (p. 93). She argued that greater community participation increases the likelihood that rules are related to the local circumstances given the community members who directly interact with the territory are able to adjust the rules in response to environmental changes (Ostrom, 1990, 2005). In addition, wider participation increases the possibility of taking into account the diversity of the territory.

Cox et al. (2010) also pointed out that community participation in the elaboration of rules is a more efficient alternative than suppressing their participation, given the territory's inhabitants have closer access to the CPRs and are therefore able to provide more reliable and lower cost information. Cox et al. drew attention to the need for some kind of control to prevent community members' participation from being co-opted by other internal or external actors or from being compromised by bureaucratic procedures.

From a behavioral point of view, CDP 3 describes a possible strategy to increase the probability that rule-making behavior is controlled by the ecological conditions of the 
CPR. Regarding local communities' participation in decision-making processes, we can consider at least two scenarios. The first is implemented through a participative model in which the community members can influence actions directly. The second is carried out by a representative model in which community members choose someone to represent their opinions and negotiate on their behalf. Each one implies a different arrangement of interlocking behavioral contingencies necessary for the production of an aggregate product, which is selected by a cultural consequence. The final aggregate product might be the same: rules that consider the local conditions of the CPR. Appropriators' behavior according to rules that lead to the conservation of natural resources will select the participatory behavior of the community members.

The participative model is characterized by a metacontingency with a large group of people who discuss, make decisions, and create rules. Alternatively, the representative model is characterized by a chained metacontingency in which the aggregate product of the inhabitants is a list of demands that is also the antecedent condition for the behavior of the representatives. There are advantages and disadvantages to both models. In the first, the participants who make the rule are the ones who know best the conditions of the CPR. However, gathering all the community's members in the same place to deliberate on a certain subject can be very challenging. Besides, it can be very difficult to handle large group discussions and to ensure broad participation. On the other hand, in the second model, it might be easier to ensure participation with smaller groups. However, given the representatives are the ones who discuss and negotiate in a second forum detached from the community's members, it might be necessary to ensure that their behaviors are guided by the aggregate product of the behavior of the inhabitants. One possibility to increase this control is to establish a systematic procedure of feedback and accountability for the community with respect to the actions undertaken. The decision to adopt the participation model must necessarily go through an analysis of what will increase the participation of people in the particular situation in a community. In both cases, allowing participation in decision making does not guarantee participation. The primary concern is what consequences will control the behavior of those participating and those who are able to implement these consequences.

At RESEX Mãe Grande de Curuçá, the deliberative council is the official body responsible for analyzing situations and formulating rules. As already mentioned, the majority of the members of the deliberative council are representatives from civil society. In this scenario, a representative model takes place. Each community has a community committee composed of five members. These committees have the responsibility to collect information, discuss, deliberate on behalf of the represented segment, and present their demands to a polo community (i.e., a central agency that brings together neighboring communities). The polo community compiles the demands from the community committee and passes these on to the association that has a permanent seat on the deliberative council.

The division into community committees and polo communities aims to organize community member participation and ensure greater representation due to the difficulty of adding 52 communities to the deliberative council that manages the RESEX (Chaves, 2010). Some community committees have intense activities to collect information from their members. Members of the deliberative council discussed the activities in these communities: 
Mr. Geraldo highlighted the importance of community meetings. Mr. Euzébio, a fisherman from Algodoalzinho community, reported that in his community an internal agreement was made between the community members for fishing and agriculture. According to him, the community itself respects the laws created and counts on the support of ICMBio. (deliberative council meeting minutes from October 30, 2017)

Other communities still need to create a solid structure for participation that ensures mechanisms for information exchange (Chaves, 2010).

Some actions that policy makers could engage in to favor the successful implementation of CDP 3 could include (a) supporting the community to evaluate the best strategy model to increase participation, taking their particularities into account; (b) promoting training in participatory processes that include content such as how to raise priority demands and how to negotiate and create rules, if desired by the communities; and (c) supporting the compilation of data concerning rule following and rule breaking and ensuring a wide dissemination of the outcomes.

\section{Core Design Principle 4: Monitoring}

CDP 4 stipulates that "monitors, who actively audit CPR conditions and appropriator behavior, are accountable to the appropriators or are the appropriators" (Ostrom, 1990, p. 94). Ostrom (1990) explained that in long-surviving CPR systems, monitoring and sanctioning are undertaken by the community members and not by external authorities. In this case, those who want to avoid opportunistic behavior also engage in observations of rule-infraction behaviors. An important aspect in implementing the monitoring and enforcement procedures is the evaluation of the costs and benefits coming from the adoption of those procedures. "The individual who finds a rule-infractor gains status and prestige for being a good protector of the commons. The infractor loses status and prestige" (Ostrom, 1990, p. 96).

Ostrom $(1990,2005)$ observed that some communities would manage their natural resources in such a way that monitoring would become a by-product. This happened, for example, when there was a schedule that rotated turns of withdrawing the resources. In this case, the subsequent appropriator served as a natural monitor for the previous appropriator. Cox et al. (2010) treated CDP 4 as having two subcomponents. The first was related to the presence of monitors: "Monitors are present and actively audit CPR conditions and appropriator behavior" (Cox et al., 2010, Table 3). The second was related to the conditions to become a monitor: "Monitors are accountable to or are the appropriators" (Cox et al., 2010, Table 3). From a behavioral perspective, CDP 4 encompasses two important elements that inhibit noncompliance with the rules: a high probability of detecting noncompliance and a high probability of punishing rulebreaking behavior once it is detected. Together, these two components likely lead to a reduction in noncompliance at a low cost.

Increasing the probability of detecting noncompliance is possible if strategies to better observe appropriators' behaviors when interacting with the CPR are developed. In this sense, it is necessary to develop discrimination training that will establish noncompliance behavior as a discriminative stimulus for the response to be punished. Some technologies can be used in this training. One possibility would be to use 
software such as Train-to-Code (Ray \& Ray, 2008), in which it is possible to insert videos of the behaviors to be punished and effectively train (with objective measurements) the identification of noncompliance behavior. Once an operant discrimination is established, it is important to add observers or increase the duration of observations in the locations where appropriators withdraw the resource. This could also be done by creating conditions (or appropriation rules) to increase the simultaneous presence of several appropriators or to sequentially withdraw the resources. This would ensure that trained monitors/appropriators are in place for as long as possible to monitor the behavior of others harvesting the resources.

Another possibility would be to use behavioral recording strategies such as those described by Johnston and Pennypacker (1993) to program patrols. Community members could be trained to select and define response classes, dimensional quantities, and units of measurement to better observe, record, and thus report noncompliance. For example, if it is observed that the number of crabs decreases in a given area, patrols could be programmed to cover the surroundings. In this way, the CPR would not need to be monitored every minute to remain protected.

Increasing the probability of punishing noncompliance depends on the monitor's behavior of applying the expected consequence after detecting an infraction. It is important to understand what the consequences are that control or might control the behavior of monitoring. Ostrom (1990) mentioned at least three potential consequences: status, prestige, and conservation of natural resources. The latter justifies why monitors are accountable to the appropriators or are the appropriators.

The objective of punishing noncompliance behavior is to supersede the individual gains that are available from illegally harvesting the resources. Once two different contingencies are in place (positive reinforcement and positive punishment), a parallel can be drawn to similar procedures that have been used to investigate conditioned suppression (Sidman, 1958). With this procedure, the first phase involves establishing a relationship between an antecedent stimulus and a punitive event; no response is required. In the second phase, a response is positively reinforced, which increases its frequency. Later, in a third phase, the antecedent stimulus (that acquired aversive properties during the first phase) is presented independently of the response that still produces positive reinforcement. This procedure results in a decrease in the frequency of the response in the third phase in comparison to the frequency of the response in the second phase. In the case of the CPR, the monitors would be the antecedent stimuli and the punitive event would involve the loss of status and prestige. As an example, disseminating a list of people who did not comply with the rules could help to add an aversive stimulus to the positive reinforcement.

Conditional suppression procedures would be useful only to suppress the behavior of community members. ${ }^{10}$ In the case of outsiders, appropriators would need to be observers who would report such behavior to the competent authorities as highlighted in CDP 1. In both cases (community members and outsiders), one may question the effectiveness of strategies to establish conditional suppression. The example of the RESEX Mãe Grande de Curuçá exemplifies how punishment could follow different

\footnotetext{
${ }^{10}$ The use of the term here is somewhat different from that used in experimental literature. In experimental studies, the presentation of the aversive event is independent of the behavior that is positively reinforced. However, in this example, punishment is contingent on the inappropriate behavior.
} 
levels of complexity, from immediate reprimands from the appropriator who witnesses noncompliance behavior to punishment by external institutions. This topic will be further explored in our discussion of CDP 5, but first it is necessary to better understand the organizational structure as pointed out by Ostrom (1990).

At the RESEX Mãe Grande de Curuçá, a three-level structure has been organized to monitor CPR withdrawal and to deal with violations. If it cannot be solved at one level, a complaint is forwarded to the next level. First, members of the community and members of community committees constantly monitor and audit the activities in the RESEX. Second, the deliberative council is the authorized agency to handle formal complaints.

Finally, ICMBio, the Brazilian Institute of Environment and Renewable Natural Resources (IBAMA), ${ }^{11}$ the police, the Public Ministry, and the State and Municipal Secretary of Fishing and Aquaculture are the authorized agencies that investigate the infractions and apply sanctions. At the first level, community members and committees closely watch the CPR. As noted in Figure 1, the campaign-advertising poster calls on community members to report the capture, transportation, and commercialization of crabs during the reproductive cycle. As a general procedure, if an infraction is detected, the community member tries to solve it by making the offender aware of the consequences to the environment and asking the offender to return the crabs to their habitat. If this is not successful, the infraction can be reported to the community committee, who can reprimand the appropriator. If the issue is not solved informally by the local mechanisms, then it can be forwarded to the second level. The deliberative council is the second level. Formally, it is the agency authorized to handle complaints. If the violation still cannot be solved at this level, then the complaint is forwarded to the third level. In the third level, there is a set of government agencies that are allowed to investigate the violations and apply other sanctions if necessary.

Policy makers might engage in some of the following actions to favor the successful implementation of CDP 4: (a) verifying whether the community (appropriators or others accountable to the appropriators) constantly monitors the areas where the CPRs are harvested; (b) supporting the community to organize a strategy to increase the probability of detecting infractions, if needed; (c) providing training on the identification of noncompliance with rules; (d) examining the consequences that control (or can potentially control) the appropriators' monitoring behavior and supporting the community to arrange new contingencies, if needed; (e) creating a safe and accessible channel to report on any violations to authorized agencies; and (f) providing data on reports, infractions, and sanctions that highlight how the behavior of monitoring contributes to the conservation of CPRs.

\section{Core Design Principle 5: Graduated Sanctions}

Ostrom (1990) wrote, "appropriators who violate operational rules are likely to be assessed graduated sanctions (depending on the seriousness and context of the offense)

\footnotetext{
${ }^{11}$ IBAMA is a federal agency linked to the Ministry of Environment, which has administrative and financial autonomy. Its agents exercise environmental police power and are entitled to undertake actions linked to the preservation of the environment, such as environmental quality control, licensing, and inspections that exert environmental police power.
} 
by other appropriators, officials accountable to these appropriators, or both" (p. 94). The graduated penalty system is based on the severity and the repetition of violations. At first, it is important to remind the violator about the importance of complying with the CPR rules. This might be enough to prevent further infractions. However, if the same appropriator breaks the rule repeatedly, it might be necessary to escalate the imposed sanctions to try to avoid a future infraction infringement (Ostrom 1990, 2005). Cox et al. (2010) argued that the system must maintain proportionality between the infraction and the sanction. A major punisher provided to a first offender might cause more harm than it provides benefit. Consideration of the circumstances under which the infraction happened to determine what sanction to apply could be a more effective strategy to prevent future infractions (Ostrom, 1990, 2005).

From a behavioral perspective, the sanction system in a self-organizing, selfgoverned, long-surviving CPR regime as described by Ostrom (1990) establishes a procedure that gradually increases the intensity or varies the type of the punitive stimulus applied to prevent reoccurrence of the behavior. It is possible to increase the intensity of the sanction if, for example, the fines range from small to large. Reprimands, fines, or even banishment are different types of punitive stimuli that can be varied with respect to intensity.

A primary feature of CDP 5 is that the type of punitive stimulus applied depends on the severity and frequency of the behavior. The community members define what is considered a mild or severe infraction and what is considered a mild or severe punitive stimulus. In order to avoid possible collateral effects, mild punishments are applied to mild or first-time infractions. If it is a severe or repeated infraction, severe punishments are applied.

At RESEX Mãe Grande de Curuçá, each of the communities has developed different systems. In some, several steps are taken before the infractions are reported to the deliberative council or the government authorities. In others, the monitors promptly report incidents to the authorities and follow the inspection guidelines. In general terms, the following sanctions are applied gradually to appropriators who break the rules: (a) a verbal reprimand from other appropriators, (b) a written reprimand from communities' committees and the deliberative council, and (c) administrative measures (ceasing crab fishing, returning crabs to their habitat, and fines) from the government and judicial investigations, as well as penalties for environmental crimes. Regarding the administrative measures, members of the deliberative council recalled that government officials also need to contribute to the conservation of the CPR:

Mr. Patrick from ICMBio . . . highlighted the role of ICMBio and IBAMA in monitoring the reproductive cycle of the Caranguejo-Uçá and the role of the [deliberative] council . . . to raise public awareness by communicating the legal basis, the periods of closure, the penalties, the definition, and importance of Suatá. [Regarding the conservation of resources], Ms. Amanda from Boa Vista community of Iririteua calls attention to the fact that there is an effort [from the community] to collaborate with the period of closure, but not the same effort to release the seized crabs by the authorized government agency. Mr. Marcelo from CONFREM [the Commission for the Strengthening of Marine Extractive Reserves] says that he has already looked for places to adequately release the crabs with the local population ... Mr. Junior from Colonia de Pescadores mentioned 
that in previous years' seizures, IBAMA did not release the crabs immediately and released into an unsuitable area, what led to the death of a lot of crabs.

Some actions policy makers could take to favor the successful implementation of CDP 5 might include (a) supporting the community to maintain a historical registry of the infractions, (b) funding research to evaluate the effectiveness of applied sanctions in suppressing the inappropriate behavior, and (c) ensuring that administrative sanctions applied by the government are also controlled by the conservation of the CPR.

\section{Core Design Principle 6: Conflict-Resolution Mechanisms}

Ostrom (1990) concluded that in self-organized, self-governed, and long-enduring CPR systems, "appropriators and their officials have rapid access to low-cost local arenas to resolve conflicts among appropriators or between appropriators and officials" (p. 100). Ostrom (1990) also argued that a rule might have multiple interpretations. Someone could use this as an opportunity to subvert the rule. Others might think that they are complying with the rule and, therefore, are making an honest mistake. To prevent these situations from happening, there must be easy access to arenas in which locals can discuss joint strategies and resolve conflicts about what constitutes an infraction (Ostrom 1990, 2005).

From a behavioral point of view, the existence of local arenas (the antecedent condition) allows appropriators' interactions (interlocking behavioral contingencies) to produce fast and low-cost common agreements (aggregate products). With the possibility of frequently reviewing, changing, or detailing the rules, it is likely that the rules are often under the control of the constant changes in local conditions and livelihood strategies (as mentioned before when discussing CDPs 2 and 3). The rules, as contingency arrangements, help to promote and maintain the behavior of checking the conditions of the CPR and discussing them with other appropriators. The aggregate product of this discussion should be an agreement as to how to manage the CPR. In turn, the common agreements are also antecedent conditions for the behavior of harvesting the resources in the future.

At RESEX Mãe Grande de Curuçá, local issues are discussed at the communities' committees. These committees were created to facilitate the comanagement of the RESEX. They receive information and try to solve conflicts. The following discussion exemplifies the process:

Colônia's president [a civil society representative] reported major problems regarding the use of prohibited fishing gear . . . RESEX Cuinarana's environmental analyst [a government representative] reported on the conservation unit's experience on spreading the word about the fishing rules and on the need for discussion and change [of the rules] through grassroots community meetings. (deliberative council meeting minutes from October 30, 2017)

If an issue requires deeper analysis and discussions that involve other communities from the RESEX, it is referred to the deliberative council.

Policy makers might (a) support the communities to increase the availability of effective local conflict resolution and (b) support training on conflict mediation, if needed, to favor the successful implementation of CDP 6. 


\section{Core Design Principle 7: Minimal Recognition of Rights to Organize}

Ostrom (1990) noted in CDP 7 that "the rights of appropriators to devise their own institutions are not challenged by external governmental authorities" (p. 101). Minimal recognition of the legitimacy of managing the CPR allows the appropriator to apply the rules without external intervention. If external agents believe that they have the right to set different rules without consulting local communities, it might be difficult for the appropriators to uphold their traditions (Cox et al., 2010; Ostrom, 1990, 2005). If CDP 7 is not followed, an appropriator might challenge a rule before an external agent. In this situation, a different reasoning in the case or a different understanding of the facts or of the relevant precedents can defy the rules created by the community and threaten the conservation of the CPR. Appropriators need reassurance that no external agent will question the rules they have created.

From a behavioral perspective, CDP 7 suggests that the contingencies described in the rules created and managed by the community must be the only contingencies operating for the behavior of withdrawing the resource. No external agency should be able to implement any other contingencies. For example, in the case of an appropriator being punished after breaking a rule, no escape contingency should be available through regulations imposed by external agencies - that is to say, no external agent should be able to remove the consequences designed by the community.

Previously we described how the government assigns the right of use to the local users in the cases of the RESEXs in Brazil. A deliberative council composed of different actors creates these rules. Although the local communities are the majority, the government and other external actors also participate and support all decisions. However, no action will be taken without the local communities' approval.

Policy makers could favor the successful implementation of CDP 7 by engaging in the following actions: (a) engaging in prior consultation in all cases where there is an intention to provide official support and (b) analyzing the rules and procedures applied by the community and avoiding the implementation of opposing or conflicting rules.

\section{Core Design Principle 8: Nested Enterprises (Used in Large, More Complex Cases)}

Ostrom (1990) referred to the existence of more than one level of interaction in more complex CPR regimes. She explained that in successful long-enduring CPR systems, "appropriation, provision, monitoring, enforcement, conflict resolution, and governance activities are organized in multiple layers of nested enterprises" (Ostrom, 1990, p. 101). Cox et al. (2010) clarified that the interactions might occur between different groups of appropriators or between appropriators and government officials at different levels.

From a behavioral point of view, CDP 8 refers to the interlocking behavioral contingencies either between appropriators at the same or different levels or between appropriators and government officials that produce specific aggregate products. The aggregate products are, then, selected by a cultural consequence.

Considering the RESEX, several examples of interactions have been reported-for instance, interactions between appropriators, community committees, and the deliberative council or between community representatives and government officials. This design is particularly interesting given other actors who also work in the territory also 
play crucial roles. Federal, state, and municipal governments are competent to promote public policies directed at the local population. Universities promote education, research, and community services. Sharing decisions makes it possible to provide integrated policies that favor the population and conservation of the CPR.

Additionally, besides other municipal- and state-level interactions, it is relevant to mention two additional national forums in which appropriators from different RESEXs are represented. The first is CONFREM. CONFREM is a national-level entity that represents the interest of more than 100,000 families living in marine and coastal RESEXs in 18 states of Brazil. Their mission is to help implement strategies that recognize the social, cultural, environmental, and economic dimensions of traditional livelihoods of the marine and coastal RESEXs. The second is the National Council of Traditional People and Communities. It is a collegiate body of an advisory nature, composed of government officials and civil society representatives from 27 different traditional groups, such as indigenous people, quilombolas communities, gypsies, extractivists, and others. The council is entitled to promote the sustainable development of traditional people and communities in order to recognize, strengthen, and ensure their rights (Decree 8750/2016). The existence of these two forums guarantees that minimal federal guidelines common to all RESEXs take into account traditional communities' experience and the conditions of the CPRs.

Policy makers could take action to ensure local community participation at every level of the decision-making process to favor the successful implementation of CDP 8.

After reviewing all the CDPs, three types of behavior seem to be crucial for the emergence of successful CPR systems that are able to conserve their natural resources over the long term: (a) rule making and rule following, (b) face-to-face control, and (c) participatory behavior in decision making. Instead of waiting for these behaviors to emerge, it is possible to influence their selection. In a given situation, behavior analysis can describe the existing competing contingencies that prevent the selection of these behaviors, and identify possible variables that can influence the probability of their occurrence or potential strategies to reduce the cost of their emission. The government might be able to partner with the communities to manipulate these variables and to implement strategies that can support the selection of these behaviors and achieve sustainability at a low cost.

\section{Looking at the Big Picture}

The behavioral processes and procedures extracted from each principle are part of a complex arrangement of historically selected cultural practices of self-organizing, selfgoverned, and long-surviving CPR regimes. Although they are treated separately for analysis, it is essential that the principles be understood as interrelated. The fragility of one CDP completely changes the configuration of the relationships. For example, if there is a graduated sanction system (robust principle 5) but no monitor to observe the behavior (fragile principle 4), it is unlikely that a rule violator will be punished. Or if the appropriation rules are related to the local conditions (robust principle 4a), but there is no definition of who is allowed to harvest the resources (fragile principle 1), it seems difficult to apply these rules. Thus, the analysis of a CPR's institutional performance as related to every principle is essential in understanding the success of community-based natural resource management. 
From a behavioral point of view regarding these principles, one could argue that the CDPs could be grouped in terms of the behavioral controls exerted. For example, CDPs 2, 3, and 7 would involve rule making; CDPs 4, 5, and 7 would involve punishment for not following rules. However, the purpose of this analysis is to emphasize how knowledge of behavior analysis can contribute to Ostrom's (1990) proposal. Thus, we considered it important to maintain the original proposal and to indicate the behavioral procedures and processes that can assist policy makers in managing CPRs.

Through the study of the local practices of the RESEX Mãe Grande de Curuçá, three situations were observed. Each situation is characterized by repeated patterns of individual contingencies and their effects or interlocking behavioral contingencies and their aggregate products, which are selected by a consequence or cultural consequence or are punished. The situations are displayed in Figure 4.

When looking at the big picture, a macrocontingency can be identified through the observation of repeated patterns of behaviors from appropriators harvesting the resources in the RESEX area (CDP 1, boundaries). Three situations were verified. Situations A and B refer to different contingency arrangements devised by appropriators (CDP 3, collective choice arrangements, and CDP 6, conflict-resolution mechanisms) and supported by the government (CDP 7, rights to organize). Situation A refers to the conditions under which collecting crabs is reinforced by the money from their sale (CDP 2, appropriation and provision rules). Situation B indicates the conditions under which collecting crabs is punished according to a graduated sanction system (CDP 4, monitoring, and CDP 5, graduated sanctions). Situation C represents alternative behaviors that can be similarly reinforced.

Only the existence of the three situations can generate the cumulative effect, which is the conservation of the CPR with renewed resources. The outcomes of this configuration are constantly monitored and evaluated. The data collected reflect the local

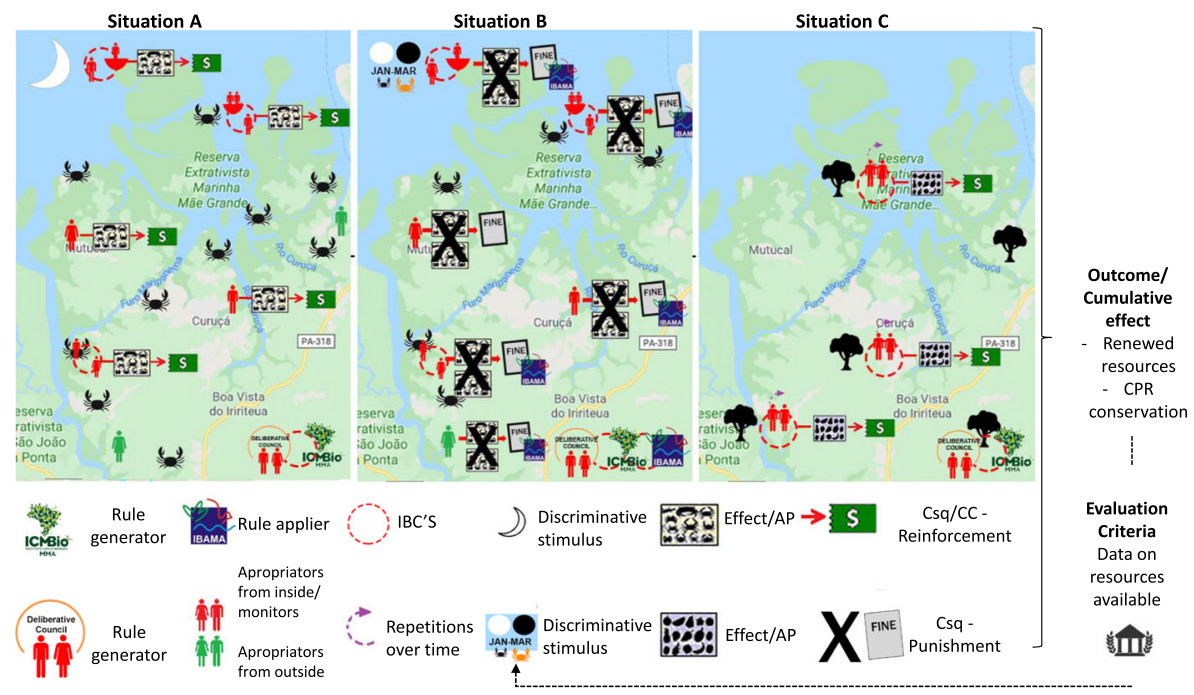

Fig. 4 CPR macrocontingency. Source: Reserva Mãe Grande de Curuçá (background), adapted from Google Maps 
conditions and inform the deliberative council who can reevaluate the appropriation and provision rules and the graduated sanctions.

Another possible interpretation might consider the choice situation that involves the magnitude and the delay of the consequence. When looking at the big picture, it is possible to observe two metacontingencies. The quantity of crabs is the aggregate product that can be exchanged for money. In the first metacontingency, the frequency of the culturant is increased by larger rewards in the short term; however, it would lead to the depletion of the CPR, impeding future use. In the latter metacontingency, the frequency of the culturant is increased by smaller rewards that could be collected multiple times over the long term, including time-out periods, leading to the conservation of the CPR.

This situation involving competing metacontingencies is similar to the one Baia and Vasconcelos (2015) reported in which two concurrent metacontingencies were programmed. The first would produce immediate positive consequences without a timeout. The second would produce greater consequences with multiple periods of time-out. Their findings showed that the metacontingency that would provide greater consequences in the long run was the one that the participants engaged in most.

This analysis is not aimed at determining whether the RESEX Mãe Grande de Curuçá is a robust or a fragile CPR system. The intention is to offer additional elements that governments might want to consider when formulating, implementing, and evaluating environmental policies. The current study focused on the analysis of cultural practices of a community as a whole and how contingencies might affect the behavior of people at a larger scale. For this reason, the emphasis was placed on concepts that have been developed more recently to help understand the behavior of persons in groups, such as metacontingencies, macrocontingencies, interlocking behavioral contingencies, and so on. However, some concepts less commonly used to explain the behavior of people who are not necessarily in interaction with others were also used to broaden the scope of this analysis.

\section{Further Reflections}

In this paper, we sought to highlight the governmental role in supporting traditional communities to conserve natural resources. We illustrated that understanding how communities perceive and comprehend their surroundings and engage with community members is essential to designing adequate interventions. By enhancing the selfgovernance of local communities, the government might be able to allocate resources efficiently and strategically toward sustainable development.

To support government agencies in this task, the integration between an institutional analysis and a selectionist approach is especially useful. Such an approach can demonstrate how the relationship between people's behavior and their environment (in a behavior-analytic meaning) should be a reference for environmental policies. Whereas an institutional analysis can describe common characteristics of successful CPR regimes and the cultural practices of their inhabitants, behavior analysis can describe how these practices were selected and evolved. This combination raises the possibility of guiding interventions that can help the emergence of essential cultural practices, especially in CPR systems that fail in conserving their resources. 
Guided by essential principles, systematized according to an institutional analysis, behavior analysts can study CPR regimes as natural experiments and reconstitute the processes of selection and evolution of existing cultural practices. By doing so, it is possible to identify which variables control the behavior of the community members and other variables that can likely affect it. This analysis can inform the community members and their associations, as well as the government, about variables that can be manipulated to help desired practices emerge.

Additionally, behavior analysts can support local communities and governments in testing different hypotheses, manipulating variables, and measuring their effect on the behavior of appropriators. Previous findings from basic and applied research on different areas such as discriminative control, choice and preference, reinforcement history and punishment, for example, might offer suggestions about different contingency arrangements that could be tested to improve rule following, participatory behavior, and face-to-face control. Findings from documentary research, quasiexperimental studies, and experimental research can spread beyond individual functional units and help in promoting large-scale social change toward the conservation of natural resources.

Acknowledgements We thank all the participants of the Think Tank 5 on Cultural Studies where the proposal of this paper was first discussed, but specially Sigrid Glenn, Maria Malott, Aécio Borba, Angelo Sampaio, Laércia Vasconcelos, and Marcelo Henriques for their comments on earlier drafts of this paper. We also thank the RESEX Mãe Grande de Curuçá community members and the ICMBio manager for giving the information we asked for.

Funding Information This study was not funded.

\section{Compliance with Ethical Standards}

Conflict of Interest The authors declare that they have no conflict of interest. The second author is a community member at the RESEX Mãe Grande de Curuçá, who cooperated in this study with the description of the cultural practices of the community.

Ethical Approval This article does not contain any studies with human participants or animals performed by the authors. The first author conducted two interviews with the second author to characterize the community's cultural practices. The quotations from the deliberative council member are derived from these interviews.

\section{References}

Almeida, M. W. B. (2004). Direitos à floresta e ambientalistmo: Seringueiros e suas lutas [Rights to the forest and to the environment: Rubber tappers and their struggles]. Revista Brasileira de Ciências Sociais, 19(55), 33-52. https://doi.org/10.1590/S0102-69092004000200003.

Baia, F. H., \& Vasconcelos, L. A. (2015). Efeitos de consequências culturais concorrentes na seleção de culturantes [Effects of different kinds of cultural consequences on cultural selection]. Revista Brasileira de Análise Do Comportamento, 11(2), 125-134. https://doi.org/10.18542/rebac.v11i2.3781.

Batista, I. M. S., \& Simonian, L. T. S. (2013). Implicações políticas, econômicas e socioambientais da RESEX Mãe Grande de Curuçá: Perspectivas de desenvolvimento sustentável no estuário paraense? [Political, economic and socioenvironmental implications of RESEX Mãe Grande de Curuçá: Prospects for sustainable development in the paraense estuary?]. Novos Cadernos NAEA, 16(1), 203-220. https://oi.org/10.5801/ncn.v16i1.1325. 
Borba, A., Tourinho, E. Z., \& Glenn, S. S. (2017). Effects of cultural consequences on the interlocking behavioral contingencies of ethical self-control. The Psychological Record, 67(3), 399-411. https://doi. org/10.1007/s40732-017-0231-6.

Decree No. 4.340. Regulamenta artigos da Lei No. 9.985, de 18 de julho de 2000, que dispõe sobre o Sistema Nacional de Unidades de Conservação da Natureza-SNUC, e dá outras providências (August 22, 2002) [Regulates articles of Law No. 9.985 of July 18, 2000, which provides for the National System of Nature Conservation Units-SNUC, and other measures (August 22, 2002)]. Retrieved from http://www. planalto.gov.br/ccivil_03/decreto/2002/D4340.htm

Decree No. 8.750. Institui o Conselho Nacional dos Povos e Comunidades Tradicionais (May 9, 2016) [Establishes the National Council of Traditional Peoples and Communities (May 9, 2016)]. Retrieved from http://www.planalto.gov.br/ccivil 03/ Ato2015-2018/2016/Decreto/D8750.htm

Decree No. . Cria a Reserva Extrativista Mãe Grande de Curuçá, no Município de Curuçá, no Estado do Pará, e dá outras providências (December 13, 2002) [Creates the Extractive Reserve Great Mother of Curuçá, in the municipality of Curuçá, State of Pará, among other measures (December 13, 2002)]. Retrieved from http://www.planalto.gov.br/ccivil 03/DNN/2002/Dnn9774.htm

Federal Law No. 9.605. Dispõe sobre as sanções penais e administrativas derivadas de condutas e atividades lesivas ao meio ambiente, e dá outras providências (February 12, 1998) [Provides for criminal and administrative sanctions arising from conduct and activities harmful to the environment, and other measures (February 12, 1998)]. Retrieved from http://www.planalto.gov.br/ccivil_03/LEIS/L9605.htm

Federal Law No. 9.985. Regulamenta o art. 225, § 1o, incisos I, II, III e VII da Constituição Federal, institui o Sistema Nacional de Unidades de Conservação da Natureza e dá outras providências (July 18, 2002) [Regulates art. 225, § 1, items I, II, III and VII of the Federal Constitution, establishes the National System of Nature Conservation Units and other measures (July 18, 2002)]. Retrieved from http://www.planalto. gov.br/ccivil_03/LEIS/L9985.htm

Federal Ordinance No. 24 (2006). Retrieved from http://www.icmbio.gov.br/portal/images/stories/imgsunidades-coservacao/portarias/RESEX\%20Mãe\%20Grande\%20do\%20Curuçá\%20port\%20024\%2009 $\% 2003 \% 202006 . p d f$

Chaves, A. T. P. V. (2010). Gestão pública e participação: Uma análise do conselho deliberativo da reserva extrativista Mãe Grande de Curuçá [Public management and participation: An analysis of the deliberative council of the Curuçá Mother's Extractive Reserve] (Master's thesis). Programa de Pós Graduação em Gestão de Recursos Naturais e Desenvolvimento Local, Universidade Federal do Pará, Brazil.

Cox, M., Arnold, G., \& Tomás, S. V. (2010). A review of design principles for community-based natural resource management. Ecology and Society, 15(4), S/n. Retrieved from https://www.ecologyandsociety. org/vol15/iss4/art38/

Galizio, M. (1979). Contingency-shaped and rule-governed behavior: Instructional control of human loss avoidance. Journal of the Experimental Analysis of Behavior, 31(1), 53-70. https://doi.org/10.1901 /2Fjeab.1979.31-53.

Glenn, S. S. (2004). Individual behavior, culture, and social change. The Behavior Analyst, 27(2), 133-151. https://doi.org/10.1007/BF03393175.

Glenn, S. S., Malott, M. E., Benvenuti, M., Houmanfar, R., Sandaker, I., Todorov, J. C., et al. (2016). Toward consistent terminology in a behaviorist approach to cultural analysis. Behavior and Social Issues, 25, 1127. https://doi.org/10.5210/bsi.v25i0.6634.

Hardin, G. (1968). The tragedy of the commons. Science, 162(3859), 1243-1248. https://doi.org/10.1126 /science.162.3859.1243.

Houmanfar, R., Rodrigues, N. J., \& Ward, T. A. (2010). Emergence and metacontingency: Points of contact and departure. Behavior and Social Issues, 19, 78-103. https://doi.org/10.5210/bsi.v19i0.3065.

Johnston, J. M., \& Pennypacker, H. S. (1993). Strategies and tactics of behavioral research (2nd ed.). Hillsdale, NJ: Lawrence Erlbaum Associates.

Matos, M. A. (2001). Comportamento governado por regras [Rule-governed behavior]. Revista Brasileira de Terapia Comportamental e Cognitiva, 3(2), 51-66. https://doi.org/10.31505/rbtcc.v3i2.135.

Ostrom, E. (1990). Governing the commons. The evolution of institutions for collective action. Cambridge, UK: Cambridge University Press.

Ostrom, E. (2000). Collective action and the evolution of social norms. Journal of Economic Perspectives, 14(3), 137-158. https://doi.org/10.1257/jep.14.3.137.

Ostrom, E. (2002). Policy analysis in the future of good societies. The Good Society, 11(1), 42-48 Retrieved from https://www.jstor.org/stable/20711048.

Ostrom, E. (2005). Understanding institutional diversity. Princeton, NJ: Princeton University Press.

Ostrom, E., \& Ostrom, V. (1971). Public choice: A different approach to the study of public administration. Public Administration Review, 31(2), 203-216. https://doi.org/10.2307/974676. 
Ostrom, E., Walker, J., \& Gardner, R. (1992). Covenants with and without a sword: Self-governance is possible. The American Political Science Review, 86(2), 404-417. https://doi.org/10.2307/1964229.

Pinheiro, E., Thomas, S., Almeida, O., \& Vergara, W. (2018). Áreas protegidas marinhas no Estado do Pará e direitos das comunidades tradicionais no processo de governança dos recursos comuns [Marine protected areas in the state of Pará and rights of traditional communities in the common resources governance process]. Cadernos de Agroecologia-Anais do VI CLAA, X CBA e V SEMDF, 13(1), s/n.

Ray, J. M., \& Ray, R. D. (2008). Train-to-Code: An adaptive expert system for training systematic observation and coding skills. Behavior Research Methods, 40(3), 673-693. https://doi.org/10.3758/BRM.40.3.673.

Sidman, M. (1958). By-products of aversive control. Journal of the Experimental Analysis of Behavior, 1(3), 265-280. https://doi.org/10.1901/jeab.1958.1-265.

Skinner, B. F. (1953). Science and human behavior. New York, NY: The Macmillan Company.

Skinner, B. F. (1969). Contingencies of reinforcement: A theoretical analysis. New York, NY: AppletonCentury-Crofts.

Souza, C. B. G. (2010). A gestão dos recursos naturais na Amazônia: A reserva extrativista Mãe Grande de Curuçá [The management of natural resources in the Amazon: The extractive reserve Mãe Grande de Curuçá]. Revista Geografar, 5(1), 83-104. https://doi.org/10.5380/geografar.v5i1.17783.

\section{Affiliations}

\section{Roberta Freitas Lemos ${ }^{1}$ - Célia Regina Neves Favacho ${ }^{2,3}$ • Kátia Cristina Favilla ${ }^{4}$. Fábio Henrique Baia ${ }^{5}$}

1 Ministério da Cidadania, Brasília, Brazil

2 Comissão Nacional de Fortalecimento das Reservas Extrativistas Costeiras e Marinhas, Marinhas, Brazil

3 Conselho Nacional dos Povos e Comunidades Tradicionais, Brasília, Brazil

4 Instituto de Ciências Sociais da Universidade de Lisboa, Lisboa, Portugal

5 Universidade de Rio Verde and Universidade de São Paulo, São Paulo, Brazil 